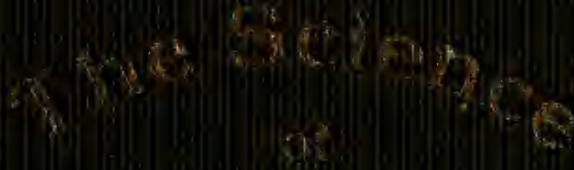

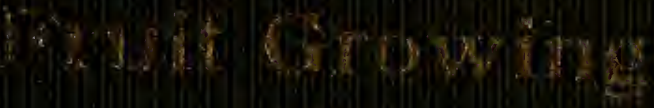

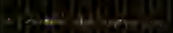

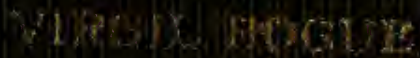




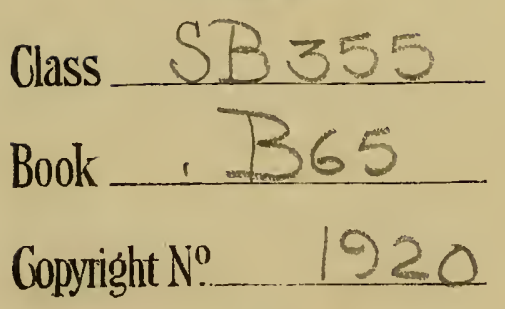

COPYRIGHT DEPOST. 



\title{
The Science of Fruit Growing AND
}

The Art of Cultivation Based on Nature's Laws

\author{
By \\ VIRGIL BOGUE \\ ALBION, NEW YORK
}

Price $\$ 3.00$ 


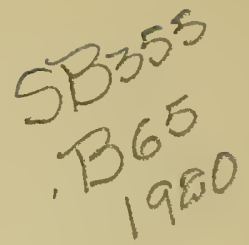

Copyrights, 1917, 1918, r919, x9zo

BY

VIRGIL BOGUE

OCT 121920

ลㄴ. 4597929 

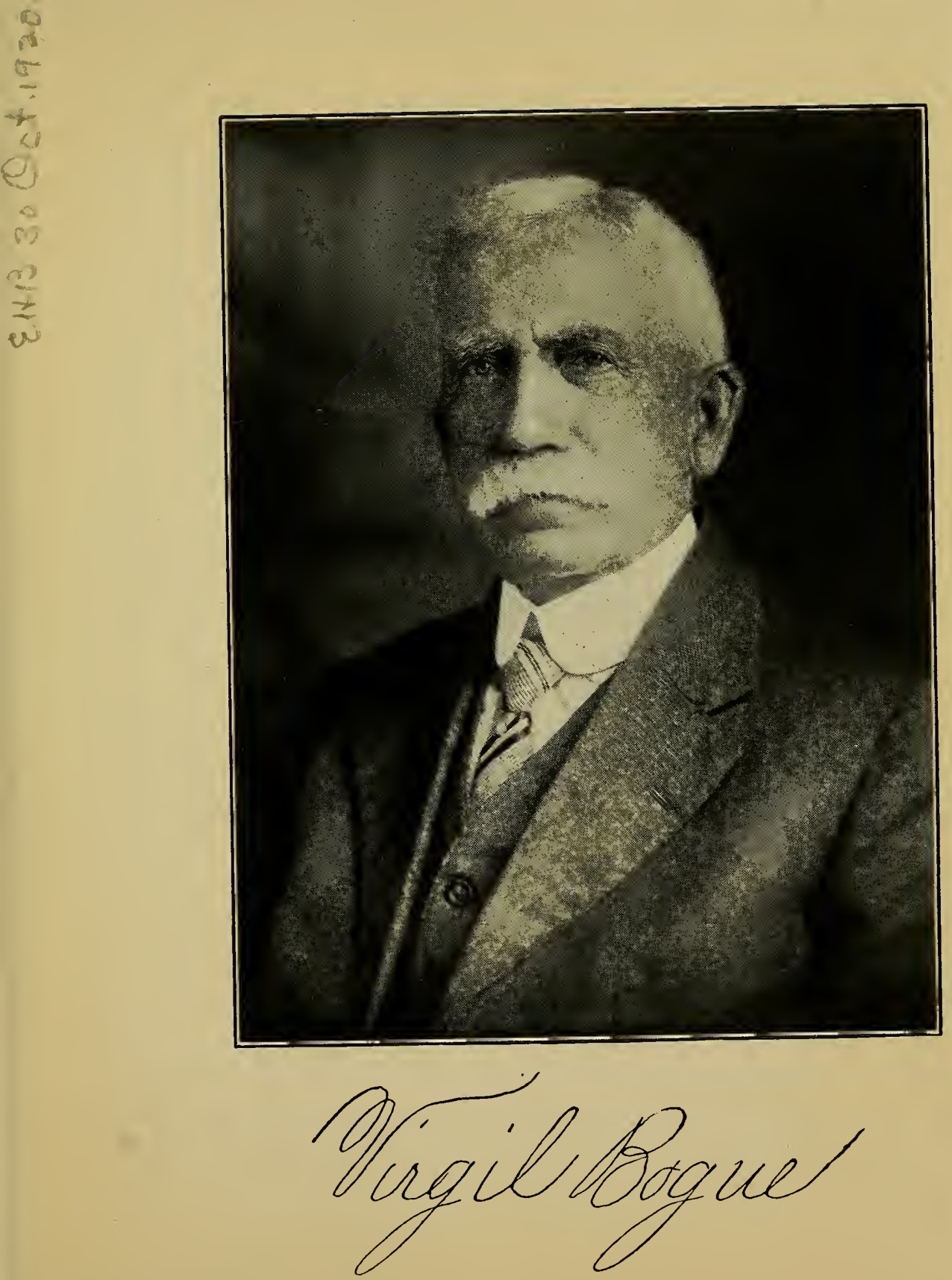





\section{THE SCIENCE OF FRUIT GROWING BASED ON NATURE'S LAWS}

BY

VIRGIL BOGUE, Albion, N. Y.

T ET us consider the great work that is

$\mathcal{L}$ being done to create and maintain the vegetable and animal kingdom in producing delicious fruits, attractive shape, fragrant and beautiful flowers of various shades and colors; and wonder who the Architect can be, how long he has been designing them, to what part are we assigned in their creation, and what shall our harvest be. 
God's workshop-what is it for, where is it, what does He make, what is the material used, and what is His great motor power?

The word God is used to designate the Creater and Controller of everything. His workshop is in the leaf of plants of all description. It consists of a system of cells corresponding to the lungs of a person, and from them there is an opening through the under side of the leaf representing the mouth and throat of a person, and apparently as sensitive in taking in and letting out the air to the air chambers of the leaf. Joining these air cells and separated from them by a delicate system of sensitive organs, is a set of cells representing the stomach, which receives the sap from the roots through a system of veins. It is in these parts where the action of the great power of heat and light make chloroplast which is the real live molecule of 
vegetable life, usually green in color as we see most leaves to be. It unites with the sap and circulates through the whole plant, aiding to reinvigorate any weak parts and to construct new parts. The making of chloroplast is the primary action for the construction of all vegetable growth on the earth's surface, and only for it, the earth would be bare of all vegetable growth and all animals that subsist on vegetable growth.

The ordinary apple leaf has about one hundred thousand breathing cells opening from the under side of it, to spray the leaves in the early part of the growing season (which is the time it is doing its best work) with a thick spray, the nature of which would form a coating over the opening of the breathing cells, would reduce the efficiency of the leaf. To spray the tree in its dormant state with a solution that will kill fungii and the eggs of 
insects, is very beneficial. If there are injurious insects in sufficient quantities to injure the fruit or tree in its growing season, it should be sprayed with a thin poison liquid that will interfere with the action of the leaf as little as possible.

The necessity for the air cells of a leaf being furnished regularly with an abundance of pure air, corresponds with the needs of pure air for the lungs of an animal. All leaves are sensitive to heat and cold, wet and dry conditions. They flourish where the conditions seem best adapted to them. Some are more sensitive to the changes at different seasons of the year than others. While the grapevine flourishes over a large area of country, it fails to develop the sugar from the starch condition at such locations as have cool nights when it is ripening. The cool air stops the working of the leaf, and the fruit remains 
in about the same condition of ripening. Though vines allowed to grow in the top of tall trees or trailed up under the eaves of a tall building above the strata of cold air, ripen their fruit to perfection, as does the vine growing in the favored location under the influence of a lake that keeps the air warm at that season of growth.

Severe electric storms have a similar effect on the leaves as a light frost. As electric storms come at the season of the year when the trees are making the best growth, their bad effect is more often overcome by elimination.

We find by observation and reasoning, that trees have life, and are constructed and maintained by the same natural laws that govern and maintain the animal kingdom. That is, they have the circulation of the sap, 
which represents the blood of the animal. This circulation is continuous throughout the growing season. We notice by cutting off a part of the top or roots during the growing season, it immediately withers and dies and in many cases where the tree is all cut off near the ground in the growing season, the roots and top both die, and we therefore conclude, naturally, that the one is dependent on the other.

The life of the tree is in its molecules, with functions similar to those in the animal kingdom to a certain extent. Some of these are constructive and others digestive and distributive. They do the work of reinvigorating by cleansing the marred or unhealthy parts, as we can see by examining the inner part of the body of the tree or large limbs, that the annual courses of growth show nearly a perfect condition, when we know they had 
been severely bruised, and many small limbs cut from them. Trees differ in their ability to cleanse and re-establish the tissues, as shown by the pine. Many of their knots are not wholly eliminated. This would tend to show that there were two circulations of the sap: one in the bark and outer courses of the wood and between them; the other from the bark to and from the heart or center of the tree. A cross section of a seasoned oak tree shows this distinctly.

The sap is quite thin and watery in the forepart of the growing season, but grows thicker as the season advances, finally reaching a state of solidity located in the bark and outer edges of the wood, to remain through its dormant season, then to be enlivened and brought into action by the warm moist atmosphere of spring, thus to continue its previous season's growth. As a proof of 
this, saw a limb of two inches in diameter from a bearing Apple tree in the spring, just as the sap is starting, and put the end in a dish of warm water, keeping it in a warm, moist atmosphere. The limb will leaf, blossom, and continue its growth until its life substance is exhausted.

As proof of the location of the life substance through its dormant stage, bore a hole one-half inch deep into a sugar maple tree in the spring, and let the sap run till it is dry; then bore it in another inch,and it will run more sap, apparently nearly as well filled with sugar as the first. This will also illustrate how the sap, in its thin liquid shape, takes up the sugar or real life substance of the tree and carries it to the leaves, to be digested or separated into its different parts, forming a new growth of wood, bark, leaves, roots, blossoms and fruit. 
We find that a higher state of vitality is produced when the roots and tops are furnished regularly with the necessary conditions and material for its growth. We want not only vitality, but matured vitality, in the fruit tree, in order to have it stand the debilitating effects of Winter, and hold and grow its fruit after it is set. Nature has furnished a sufficient amount of this in the tree to produce occasional crops of fine fruit in those sections where fruit naturally grows.

The fruit grower finds it necessary to do something more to aid the tree in securing its moisture more regularly and its feeding material more abundantly. The bacteria that is necessary to decompose vegetable matter in the soil, in order to make plant food available for the feeding of the roots, does not do its best work when the soil is crusted, hard, or covered with sod, but does it when the ground 
is frequently cultivated and broken up into fine parts, so the air is readily admitted to the place where the decomposition is going on, and is facilitated by the abundance of fresh air that enters into the process of decomposition of vegetable matter, and the growth of plants.

The tree can not live any great length of time with its roots in water. Neither can it produce a regular and sufficient circulation of its sap without moisture in sufficient quantities to supply its needs. The nearer we can furnish regularly the needed moisture, and in its proper season, the more matured vitality it will possess, and like the hill of corn, the size and maturity of the ear it produces depends on the amount of matured vitality in the stalk. For instance, a hill of corn planted early and which through neglect dries up, produces little, and one planted late produces 
an immatured ear of but little value. The fruit-bearing tree is as sensitive to cultivation as a hill of corn. They both use the same conditions for their growth. To obtain the best results, they both need to be planted far enough apart so that the sun can strike the land where their roots feed. A root grown in the sun is worth more for producing matured vitality than one grown in the shade. This is readily shown by trying to grow either in the shade of a building.

Trees bear best when furnished apparently an excess amount of fertilizer, and the land well plowed, thoroughly and often cultivated, from early Spring to the first of September, then seeded to chickweed or some Fall plant that grows mostly on moisture. One reason why orchards located near lakes bear more regularly than those inland, is that moist cloudy conditions that aid the trees in 
growing at the season when the fruit bud is maturing its vitality for the following year's crop. Trees growing further away from the lakes are more often matured by the sun before they are fully developed. They both appear to blossom about the same, but while one holds and grows the fruit, the other more often drops it before maturity. This relates to trees growing under neglect and depending entirely on natural conditions.

Where the trees grow under more sunny conditions, and are furnished the necessary moisture and food regularly by cultivation, they produce good crops of better colored fruit, which means better flavor. Fruits, like flowers, reach the highest state of perfection in proportion to the amount of sunlight they receive, other conditions being equal.

The individuality of the fruit is a germ 
much smaller than the head of a pin, located just under the base of the bud in a jet. If a jet of a Greening or any variety is transferred to another variety and grows, the fruit born from it would be of the variety from which it was taken. This is called budding, and by it one tree can be made to produce many distinct varieties of apples. The budding should be done when the new growth is nearly matured, and the sap in the tree to be budded is beginning to thicken. Under such conditions the bud and the tree unite readily.

Trees do not produce fruit in the younger stages of their growth. Like the animal kingdom, they seem to require a matured state for reproduction. The growth of the fruit spurs represent the necessary matured condition for reproduction. The first blossoms on a young tree seldom produce fruit, as the tree has to advance beyond that stage. 
One leaf will not produce fruit. It requires a number, and the larger proportion of leaves to a fruit, the better and the nearer the leaves to the fruit, the better action they have in producing it.

Each variety of fruit has its special seasons and necessary conditions to develop and mature its fruit germ which is done the year before it bears fruit. The productiveness of a tree depends in a large measure on the structure of the leaf and its adaptability to conditions. To illustrate, take the Greening, its terminal leaves are usually the largest it produces in the season, indicating that the maturing of the tree is continued till the last of the season, and is generally known to be a great and regular bearer of fruit. In contrast to this we will take the Esopus Spitzenberg, the leaves of which are the smallest at the last of the season's growth, and taper back in 
size to those grown in mid-season. That does not represent the best conditions for producing a developed and mature condition of the germ. Hence it is only under the most favorable conditions that this variety bears. Other illustrations are numerous.

When starting an orchard, it is best to secure nursery trees that have been budded or grafted from bearing trees, as in many cases they have been rebudded from nursery trees for a dozen or more generations, which eliminates in a large measure the nature of reproduction of fruit, and they do not bear as young as when budded from bearing trees. The tree should be cared for from the time it is dug from the nursery until it is planted, in the best way to keep it from deteriorating in vitality by drying up or the roots being frosted when out of the ground or exposed in a cold room or put in water, especially cold 
water, as it requires more attention to reinvigorate it after its vitality has been reduced fifty per cent. or more by transplanting. The trees should be planted in a good pulverized and moderately rich soil, and have the dirt packed well around the roots. The roots can be puddled in a thin mud before planting, but never wet down the dirt in the hole when planting, as it later produces a hard, drybaked condition that may require a year or more to change to be like the surrounding ground, in the meantime the tree will do poorly. If a farmer was asked how he would treat a small piece of ground so that it would not grow weeds or anything else with natural thrift, he would reply: "Spade it in the Spring when wet, and stamp it down thoroughly." This is the way many plant trees. The tree should be given such care as is necessary to furnish its requirements for a con- 
tinuous growth, from the time it is set until it dies of old age.

Trimming should be started from the beginning by cutting off all mutilated roots smoothly, when planting, so they will callous more readily and start fine roots. About onethird of the ends of the last year's growth. of the tops should be cut off, in order to start the new growth from well-matured wood. The centre of the tree should be allowed to grow and be maintained throughout its whole existence. After the first year the side branches should be cut off to within six inches of the tree, and allowed to produce all the side growth they can of any nature. The following year anything growing on the short growth over six inches, should be shortened to six inches, and also the side growth on the center, until the tree reaches a height at which you want the first permanent limb to 
grow, and then leave a limb for permanent growth, and above that six inches to a foot on another side of the tree leave another limb, proceeding in this manner until five or six have been left for permanent growth. These should be cut back a little on the ends, and the limbs making too large a growth on its sides, in order to force a production of as many fruit spurs and short growths on the body and main limbs as possible. The leaves on these short twigs serve to make the main limbs stocky and are performing near it their office of developing the whole tree, root and branches. Where there are no short twigs and the sap has to traverse a long body, and then a long limb to reach the few leaves at the end of it, and return lightly reinvigorated with chlorophyll to construct and reinvigorate the roots, it can not be expected that such a condition would produce as favorable re- 
sults as would follow where the body and large limbs are more covered with short twigs and fruit spurs.

Under the latter condition you would seldom see any water sprouts that Nature is always producing on large bare limbs. Four or five feet above the first started permanent limbs, should be grown another lot and so on, as high as you wish to have the tree grow. Always aim to produce and preserve as many short twigs on the larger limbs as is possible. If the short limbs grow too strong and fill in the inside too much, cut them back, and so force out more fruit spurs on them. Remember, that one leaf does not make an Apple and that the more fruit-spur leaves you can produce on the body and main limbs, the better. A large percentage of the fruit will grow on these short twigs. There are many orchards in Western New York that are practically and 
scientifically trimmed under the present system of culture, that are in such a weak state of vitality that many of their limbs are dying from exhaustion, the sap not being able to traverse the distance necessary to reach the leaves on the ends of the limbs, and then return with the necessary nourishment to continue life, and that too under good conditions and cultivation. For the most part these trees do not and cannot produce as many pounds of fruit as they did ten years ago, or what they could have produced if they had never been trimmed. Trees properly trimmed from the beginning under this plan, would eliminate the necessity of cutting out large limbs in later years, as is very often the case. Every time a limb or root of a tree is cut off, it injures the tree. There are some seasons of the year when to trim a tree injures it most. We are often told that the time to cut 
bushes or trees to kill them is in August. The reason I assume for plants dying when cut at this time, is that the tree or bushes has reached its highest state of growth, and begins the maturing of the growth, which it is not able to do without the aid of the leaves, decomposition sets in, and it dies. To trim trees late in the Fall or Winter, exposes the tender inner part of the bark. The freezing and thawing makes a bad sore, which extends much farther under the bark than is apparent from the outside and has to be reinvigorated by the sap in summer, the same as the blood heals a sore. On nursery trees, where the results are more readily observed, it has often affected the trees so badly, especially the Baldwins, that the heart would become black and punky, and in later years the tree would become worthless and die.

A little statement in a book on tree culture 
sent out many years ago from Rochester, N. Y., stated: "Trim any time your knife was sharp." This was the cause of many thousand worthless trees. To preserve the greatest amount of vigor the tree should be trimmed just before the leaves start in the Spring. To trim just after the leaves start is very weakening. It grows less injurious as the season advances, up to about July 1st, after which it is more injurious on fruitbearing trees until Winter. Where large limbs have to be cut off, it should be at the collar and not in the shoulder, as the shoulder possesses the healing nature of growth and the limb does not; the cut should be immediately painted with linseed oil and iron ore, to keep the fungii parasites out until it can grow over. Never use any animal oil on trees unless made into soap.

The functions of the roots are to serve as 
the stomach of the tree, to receive the moisture and food necessary for the maintainance of the tree. They work in conjunction with the leaves, which act as the lungs. The success of this depends on the amount of moisture and food available and the regularity with which it is obtained. Our ancestors found that by plowing and cultivating the soil, plants and trees produced a greater growth and yield than when planted in solid ground: in most cases the more the land is cultivated, the larger the growth.

The roots of trees vary, according to the depth of the soil they flourish in, and also depend on the variety of the tree and the solidity of the soil. They require a certain amount of healthy air, light and sunshine, and they thrive best where they can best secure these. An excess amount of moisture in the ground at the growing season for an 
extended period reduces the quality of the sap in an Apple tree until it weakens and dies. If it does not kill the tree it very often prevents it from producing enough matured vitality to hold its fruit after the blossoming season for that and the following year. When the ground becomes very dry from the Summer drouth, the root will go deeper into the ground, seeking moisture. As the stronger of the roots will take the lead downward, many of the smaller roots become inactive and die. The root has the same nature as the top, in always sending out branches to gather its requirements. Often they get so deep that the Spring rains following, drown them out for the want of air, they die, and the tree starts out roots near the surface again.

If we can reason that the tree requires matured roots, the same as the top requires matured fruit spurs in order to produce fruit, 
then many of the trees' failure to produce, may be accounted for and very strong evidence of the value of cultivation, which keeps the roots near the surface of the ground. Also this demonstrates the value of deep underdrains. A root grown where the sunlight can strike the earth above it, is much more valuable than one grown in the shade.

The place to put manure is outside the shade of the tree, to have it do the most good, for the more roots feeding in the sunlight, the better. Nearly all substances subject to decomposition by the ground are good to produce growth. Vegetable and mineral substances are better than animal. Warm, moist ground is a great deodorizer and decomposer of manural substances. Dry ground is much less active or efficient.

As trees and plants get their nourishment 
from the soil through the roots, it is well to keep the soil in as good condition as possible to feed the roots all the time the tree or plant is growing. The ends of these roots are porous, like a sponge, and absorb the moisture, which is in the form of a film surrounding each grain of soil, and is enriched by the material in the grain of earth and the gases and spirits formed by the decomposed manural substances in the soil, by action of heat and moisture, and then conveyed to the leaves by capillary attraction. The quality of the moisture called sap, so obtained, depends on the available proportions of potash, phosphoric acid and nitrogen as necessaries, and lime, iron, magnesia and other chemicals as assistants. Nearly all vegetable substances, except a few heavily laden with acids, that are susceptible to decomposition when well assimilated in the soil under action of heat 
and moisture, make good plant food. The fomenting condition of the soil is kept even and continuous in proportion as the soil is kept cultivated under favorable conditions.

A barrel of fine refuse salt, sown evenly over an acre of finely pulverized dry land, will aid in promoting vegetable growth in a dry time. Care should be taken not to sow it in lumps or piles, as the impurities in salt draws moisture from the atmosphere. If the dense liquid or brine formed by it should come in contact with the roots of the trees in sufficient quantity, it would draw the less dense liquid or sap from the roots, and kill them the same way that it kills grass, viz., by drawing the moisture from its roots.

Light acting on the leaves develops chlorophyll, which is the green color of vegetation. It digests or elaborates the sap, which 
fits it for the production of new cells that form the extensions of new growths of leaves, wood and fruit. The solidity of the vegetable or fruit depends on the amount of light the leaves receive. The leaves should be kept as free as possible from all fungii or foreign substances and in a growing condition, that its cells may be open to receive the light, and not dry up from lack of sap. When in a healthy, growing condition the leaf absorbs oxygen and hydrogen from the air in the day, and casts off surplus oxygen and carbonic acid at night. The oxygen is necessary for its development, and the carbonic acid becomes a foreign substance to be eliminated for the health of the plant. If the leaf is not able to receive oxygen freely, or if there is a lack of free elimination of the foreign substances, it would create a clogging of the growing system and produce bad re- 
sults, the same as in the animal system. The plant, in trying to eliminate foreign substance in the growing season, caused by frozen cells, is often overtaxed, and dies, or continues its life in a weakened state, producing little results.

If the frozen part of a tree or plant could be removed by cutting it off as soon as it is frozen, it would save the tree or plant from having to eliminate the foreign matter or dead molecules in the sap through its regular system of growth. The ability of a tree to recover from the effects of a late Spring freeze, and mature its fruit, depends on the amount of matured vitality it has to aid its growth, and the severity of the freeze.

It is more exhausting to a tree to let it hold its fruit until it ripens and drop off itself, than it is to pick it off as soon as it is ready 
for the market. The difference in many instances means a failure in fruit production the following year. It is injurious to a tree to allow its fruit to decay on the ground under it. As far as possible it should be removed. The dead leaves seem to be good fertilizer, and they should be held on the ground as they fall by some late fall growing plant until plowed under. To plow the land in the late fall or early winter, kills many of the insects that winter in the ground. The leaves and plants plowed under are ready to decay in the Spring as soon as the warm weather develops the bacteria necessary for decomposition, and so becomes available for plant food. The fungii that is on the leaves and rejected fruit, develops in the Spring, when the leaves and rejected fruit are allowed to remain on the ground, into millions of spores at a temperature of 45 degrees, which float in the air, 
alighting on everything with which they come in contact, but only grow where they can get nourishment suitable for their needs.

The most of fruits, like grasses, have a better flavor when harvested just before their seeds ripen, and allowed to cure or ripen slowly in a cool place.

The highest state of perfection in the fruit is produced where it has been regularly furnished its necessities for growth while in its tannin, starch and sugar stages. An imperfect tannin cannot produce a perfect starch, and an imperfect starch cannot produce a perfect sugar, which are the different stages of growth in the fruit.

For want of application a very little benefit is being received from our knowledge of the beneficial animals, birds and insects. There are enough of them if they were prop- 
erly fostered to destroy all the injurious insects that injure the trees and vegetable plants.

There is the skunk or polecat, which is a busy worker at night--when it feels free to roam without being molested, it has an instinct to detect grubs, snailes and other insects, when it is walking over the ground, located at a depth of two inches from the surface of the ground, and digs them out for its food. It is shy of people, and only uses its power of defense when in danger. It lives mostly in burrows in the ground in localities where it is not likely to be molested.

The snake, of which there are many kinds that are harmless, lives mostly on mice, ground moles, insects, and berries. They live mostly in stone piles, a fence post set with stones around it makes a satisfactory place 
for them to live. The toads live on insects gathered with their tongue, which is extremely long and so constructed that it can catch and hold a very quick insect. It likes to live under a flat stone raised just far enough above the ground for it to enter. A few such homes located along the edge of the garden would soon be well occupied, and a great reduction of insects in the garden would follow.

The wasp, hornet, sweat beas, and lady bugs, are great butchers of insects and eaters of insects' eggs. The wasp stings many insects-among them the green pear wormuntil it dies. It then drags it to a place where it has a hole in the ground, where it puts it, then lays an egg in the worm and covers it up, apparently with a satisfaction that it has done something to perpetuate its kind, as the larvae formed from the egg feeds on the decomposing insect. They prefer to live in a 
quiet place, often in the top of a building that is not much frequented by people.

The hornet does the same killing of insects, but it prefers a hollow stalk of a plant in which to put the insect, and deposit its egg. There are different kinds of birds that are great devourers of insects and possess a wonderful instinct for locating them. The woodpecker has the instinct to locate a grub feeding in and under the bark of a tree, and has strength in its bill to drill a hole and get it to eat. It is continually hunting on trees for insects. It likes its home in a dense wooded ravine, where it raises its young in a hole in a tree that it has made with its own bill.

The Creator has provided all these and many other helpful animals, birds, and insects, with a nature of reproduction and to 
seek seclusion for their homes. They would be of great benefit if they were protected, instead of often being foolishly killed.

To understand these conditions and try to produce them will give more and regular compensation for the labor and expense bestowed on the producing of fruits, vegetables, grains and flowers.

Apply the principles herein advanced to the care of your orchard, and note results. 




\section{THE SCIENCE OF FRUIT GROWING BASED ON NATURE'S LAWS}

Part II.

The fruit growing season in the Western New York fruit belt is too short to develop and mature the commercial varieties of fruit now grown in that section. The Newtown Pippin, Peck's Pleasant, Wine Saps, Spitzenbergs and other varieties are finding better climatic conditions in the Virginias, and when grown there they are supplying the markets at a higher price and in a much more satisfactory manner than when grown in their earlier home, Western New York, where the 
climatic conditions in an earlier day made them famous.

Everything that can possibly be done should be done to lengthen the growing season, especially the fore part of it.

By plowing the land in the late Fall or Winter and cultivating into the soil a coating of partly decayed stable manure, the bacteria would start in the soil much earlier in the Spring, and when once started it increases very rapidly and spreads throughout the adjoining soil. It starts very slowly in unplowed land and where no stable manure is applied often makes a difference of several days in the condition of growth.

To get the greatest benefit from stable manure, aside from what is necessary to start the bacteria on or near the surface of the ground, it is better to plow it under from five 
to eight inches deep. The soil absorbs the different properties in the manure as it decomposes and holds it till the roots of the plants can absorb it. If allowed to decay on the surface many valuable manural properties are carried away by the air, which is a great absorbant.

Covering the land with a thin layer of manure or any vegetable substance is bene.ficial to growth. It prevents the air from taking the manural substances and moisture from the ground and maintains a more even temperature in the soil. Care should be taken not to apply too much stable manure late in the growing season, as a heavy rain would. carry to the roots an over-supply of food at a time when they could not use it and make a matured growth.

The bacteria plays a very essential part in 
the growth of plants. There are many kinds of them, some beneficial and others injurious. Each kind exists under conditions adapted to their nature. The kind that works in wet muck or low lands, producing a coarse swamp grass of little value, is not the kind wanted to produce good apples. Apple trees would soon die if forced to grow under these conditions. The elastic nature of plants and animals is such that they can exist for a short time on unnatural food, which when extended too long will show detrimental results.

Different kinds of bacteria, under the right kind of conditions, help to grow different kinds of plants requiring the same conditions for growth, and if their seed is not there they seem to produce these plants spontaneously.

The season of the year controls the great 
power of heat and light in the production of new growth and the ripening of the condition that exists at the time, whether fully developed or not, which accounts in part for small size fruit and grain. Every distinct variety of plants or fruit has its season for ripening its seed and stock, after which its growth, if any, is to store life substance for the maintenance of the stock and the starting of another crop of seed. Much depends on the condition of growth when the ripening season strikes it. Judging from a financial standpoint, it determines whether the product will have a high or low value and whether the individual specimens will be large and well matured or small, imperfect and of little value. All that can be done to help furnish Nature's requirements in the proper season for growth, will show results at harvest time. 
The respiratory organs located on the body and larger limbs of old trees are not able to serve their purpose, owing to the dead bark covering the surface. This bark should be scraped off in the Spring before the tree starts its growth. Extreme care should be taken not to cut into the green bark under it. This gives the tree a chance for a free respiration throughout the bark, where the organs inhale and exhale air and moisture. The body and large limbs that have been scraped should not be covered with a thick whitewash in the growing season, any more than the leaves should be covered with it. When the body is covered with little twigs the pores are more numerous near the base of the twigs. The development of the respiratory organs is what makes the tree larger in their vicinity, or what is more commonly called "stocky," 
and are more valuable to growth than long, slim limbs. It gives the tree a better circulation of its sap upwards as well as downwards through the body. A clearer conception of the extent and working of the respiratory organs can be obtained by taking a section of the bark, two feet wide by three feet long, from a basswood tree about the longest day of Summer, at which time it peels freely, from the tree, put it in a running brook for four weeks; weight it well, so it will not rise above the water. At the end of the four weeks, the life substance located between the layers of bark is well decayed and there will be eight or ten layers of thin bark that will readily separate from each other and from the outer layers of dead bark. These layers are very porous, the perforations ranging from the size of the point of a pin on the inner bark to $1 / 16$ of an inch in the outer layers. All tree barks 
are similarly constructed, but not so easily examined as the basswood. These pores connect the life of the tree located between the layers of bark and the outside of the tree. There are many thousands to the square inch of bark surface in a young healthy tree.

Many of the old bearing trees under the present system of trimming and culture are barkbound, which causes the elongated cells through which the sap flows to and from the roots, to be contracted or depressed, and this interferes with the free circulation of the sap. This condition can be 'relieved by cutting perpendicularly through the bark of the body from the roots, to and along large limbs on three or four sides of the tree in June, at which time new wood and bark are commencing to form; the bark, being nearly loose on the tree at that time, can more readily adjust 
itself to the expansion which in bad cases would be more than one-fourth of an inch at each cut.

Nothing should be done to the tree or plant that would hinder a regular or progressive growth, or allow any condition to exist that would require a large per cent. of chlorophyll throughout its growing season to be used to eliminate foreign matter, or to reinvigorate the parts that are unfavorably affected from exterior causes. All the chlorophyll so used reduces the amount that would be available for the production of fruit or grain. The debilitating effects of Winter on bearing trees is great, especially if they were not well matured in the previous Fall.

If the amount of needed trimming is so great that it cannot be done at the best season for the good of the tree, it can be done in 
late Winter by leaving stubs on the tree from one to two feet long, and cut them off later at the proper time, which will be less injurious to the health of the tree. The frozen sore that is on the end of the stub is not in the main course of the sap's circulation from the roots to the leaves. The bad effects of the poison to be eliminated from it is not so great. It is better to remove the stumps before the circulation of the sap is commenced in the Spring.

Judgment should be used in deciding the depth to plow the orchard. If the previous Summer and Fall were dry, then it will do to plow deep, as the active feeding roots are deep in the ground. If the previous Spring and Summer season was excessively wet, then the active feeding roots are mostly near the surface, and should not be cut off by plowing 
too deep. The deeper the land can be plowed consistent with the position of the roots of the trees, the easier it will be to conserve the moisture by cultivation through the dryer part of the growing season.

Spraying with poisons and fungicides are temporarily beneficial to keep fungii and insects off until the fruit can be used. They should not be depended on to take the necessary place of food and care to produce fully developed and mature vitality, any more than we should depend on spraying with insecticides to keep the cows of a good dairy free of insects, when we know by giving them plenty of feed that is adapted to their needs and good care, they are not infected with insects or fungii. No kind of Aphides or lice can live for any length of time by feeding on the leaves of strictly healthy trees or plants, 
nor can they live on a well-fed and cared for animal. Fungii grows on a leaf, tree or fruit, only where there is an imperfect and immatured condition of growth. The imperfect condition of an apple that has fungii on it can be seen by placing it in the air till it shrivels, then put it in a vacuum where the air can be taken from it, and it will show that the cells covered by the fungii are brought out full again, indicating that that part of the apple which is usually near the blossom end was immatured and could not stand the air pressure when compared with the stem end where there is little or no fungii.

The beautiful colored leaves that we see in the Autumn are the result of an imperfect maturing and deteriorating condition of growth. The most distinct scarlet coloring is produced by taking all the bark off near the roots of a silver maple in late Winter that is 
standing near a pond or stream of water, where it has had a chance to produce a perfect growth. By girding the bark at that time of the year there is nothing to make a new bark form. The sap goes up the tree, through the outer layers of wood, and when it: returns through the layers of bark, there is a disconnection at the girded place. The tree not being able to make a perfect growth, which it would have without the girdle, it commences to die, and in the process it develops in the leaf the mineral coloring that is contained in the life substance of the tree. Some trees showing scarlet and crimson leaves that are affected by the drouth, are injuries that are less fatal and under favorable conditions it continues growth the following season, and wholly recovers, or may continue living in a weak condition for a few years before finally dying. 
If the respiratory organs with which the bark is completely filled should cease their action from the effects of the first cold nights in the Fall and shut off the return of the sap to the roots, it would produce a similar effect to that produced if the tree was girdled at the roots.

The apple colors very fast if left on the tree after a frost, which is a most drastic stopping of the formation of chlorophyll, without which the chemical coloring in the sap is more apparent. Trees that ripen their fruit in Summer develop its coloring on the fruit as it reaches its ripening stage, in most cases of which it is a deteriorating condition. Much depends on the construction of the individual nature of each variety and the favorable or unfavorable condition under which it exists. Trees and plants whose foliage throughout 
their growing season are other than green, are so by primary construction and not so constructed by the process of growth. The most brilliant coloring in the leaf and fruit is produced from the tree or plant that has the highest state of matured vitality in it at the time the ripening process is commencing, and the more rapid will be the change of coloring. A bearing apple tree living under conditions of slow growth, develops the coloring of its fruit much better than a tree that is making a more rapid growth, as it is near the ripening stage most all the time. As an illustration of a checked or stunted cundition of growth produced, we will yrow a tree by grafting a Baldwin scion on a Northern Spy tree that has been set in the orchard long enough to develop its bearing nature. The Baldwin variety, under the influence of heat, light and moisture, starts its growth in the 
Spring about ten days earlier than the Northern Spy, but is not able to do much growing until the Spy is growing enough to feed it. In the meantime the Baldwin has been existing on its stored vitality, the same as a limb cut from a tree with the same results. When the fruit on that kind of a Baldwin tree is about the size of marbles, it is red and in the most cases continues so to be until Fall, and not being sufficiently fed are undersize to what we get by growing the tree on other varieties that start their growth at the same time.

We often see fruits that are checked from climatic causes, when in their earlier growing season, show high coloring from that time till harvested. Once the component parts of vegetable life are chemically separated, they remain so unless by nature it is reinvigorated with chlorophyll. 
When the leaf stops making chlorophyll, or if the growing fruit is not able to get per. fect chlorophyll, deterioration commences and the chemicals in the sap show their coloring, which is usually yellow. When the fruit in that ripening stage is receiving direct or reflected rays of the sun, it shows red. The late June drop of the red varieties of apples or a partly grown apple that is killed by a worm feeding on its vital parts, turns red in the process of dying. It is of a dingy color, it not having reached a degree of maturity to form perfect chemicals for the bright red coloring.

Nature seems to have a gauge by which it determines the amount of fruit to set from the multitude of blossoms. It seems to be based on the degree of development of each miniature part, judging from the kernels of 
corn set from the abundance of silk representing the cob or ear. The kernels on the ear with a few exceptions are without a vacancy from the stock end of the cob as far on it as they are produced. Many other grains show a similarity of setting.

The blossoming feature of everything seems to be well organized. It takes wellmatured and real life substance to hold and grow the fruit after it is formed.

The amount of pink coloring in the petals of fruit blossoms, especially the apple, and the length of time it holds it before turning white, represents the degree of matured vitality in the tree. Without the pink coloring in the petals the ability of the tree to hold and grow its fruit till picking time is uncertain. It is an indication of an undeveloped condition in the tree or its vitality has been greatly reduced by the elements of the weather. 
The trees in setting their fruit are for the production of seed and are often too numerous to produce the size of pulp that is desired by the consumer. The fruit apparently is set too thick to produce the large specimens desired. They should be thinned, in order to give more nourishment to those that are left for development. In thinning the fruit it is best to use shears that are made for the purpose, as in removing a fruit when young by hand, it often loosens the one adjoining it with bad results. The thinning should be done as early in the season as it becomes apparent that it should be done, as by so doing it will conserve the life substance of the tree to grow what is left. It requires all of a hundred times the mineral substance to grow the seed, core, pit and stem of fruit, that it does to produce the pulp, the development and perfection of which is the grower's desired product. 
When a fruit-bearing tree suffers from a Summer drouth, it is caused by the roots not furnishing the necessary moisture and food. It lives on its vitality, and often is reduced till it is not able to complete the growth of its fruit as shown by the weak cells near the blow end. It is not likely to produce fruit the following season, though it may blossom profusely.

Ripening is a condition formed by the stopping of the making of chlorophyll in part or whole and is controlled by the climatic conditions. For example, a red-nosed, white or yellow corn will not develop coloring on the kernels if the making of chlorophyll is suddenly stopped by an electric storm, or frost before it reaches a sufficient development, so that the chemicals forming the sap can separate enough to show their colors. 
Other examples are numerous. When in that state they can only be prevented from decaying by evaporating the moisture from them. They being an incomplete organism, are unhealthy for food. If eaten, it has to be eliminated from the system as poison, if not by the organs intended for that work, then by an exodus through the skin, as exemplified by pimples, boils, carbuncles, etc., instead of being an assistance for maintenance. They are on the same order for assimilation as tainted meat, spoiled eggs and partly decayed vegetables, or those whose development was prematurely stopped through blight.

To produce a perfect fruit, vegetable or grain, there should be all the requisite elements in the soil in a soluble state to make a perfect growth. The plant should not be obliged or necessitated to make lime take the 
place of potash or other essential ingredients, as it oftentimes is.

It is almost impossible to keep the leaves clear of miniature lice and fungii when grown on imperfect food. Phloxoria, a most dreaded parasitic disease of the grape leaf of long standing in France, was eliminated by applying a liberal amount of potash to the soil. There are other improper ingredients in growth, that if known and corrected would save much spraying and produce a better article of food.

Barring the bad effects of an injurious climatic condition, fruit-bearing trees ought to bear a fair size crop of perfect fruit every year if the tree is given proper care and nourishment and the fruit thinned sufficiently to enable the tree to develop the fruit without its exhaustion below a normal growing condi- 
tion. This can be done without the use of fungii sprays or poison except in a few cases, and those only till we can learn how to combat them with nature's agencies and put them in operation.

Many fruit trees would be more profitable if they were grafted to other varieties which can be done any time in the Spring after the heavy freezing weather has passed, till the leaves are half grown in size. The best time to do it is just before the buds start on the tree, as it would soon be ready to furnish sap for its growth. About one-half of the large limbs should be grafted each year, leaving one year between the grafting. This will leave enough leaves to make the necessary amount of chlorophyll to keep the tree in a normal condition of growth. After the second grafting has made one year's growth all 
the remaining ungrafted limbs can be removed. The scions should be cut from bearing trees in the Fall after the leaves on them have fallen and before there is hard freezing weather. The scions should be put in a separate tight box, packed in hay, straw, waste or sawdust, and put in a cool place where they will not freeze, till used. The middle third of the scion is the best to use. There is so much sap passing over the first third of the scion from the tree end, the buds do not fully develop; if used they are so slow in starting to grow that they do not prove satisfactory. The last third of the scion in the most of varieties are not fully matured and are more likely to dry up when grafted before they can receive nourishment from the tree. The stub should be grafted as soon as the limb is cut off, the end of the limb and the crack on the sides of the limb that was made by the split- 
ting of the limb, in order to insert the scion, should be covered with wax and at least four inches below where you can see the crack, as the bark often dries and shows the crack extended below what is apparent. The waxing should be done to keep the air out. A little wax put on the end of the scion will keep it from drying. The scion should be cut wedge shape for at least one inch, with two buds on it. When set firmly in the crack made by splitting the end of the limb, the inner part of the bark of both the scion and limb should come together, to make sure the scion can be set a little crossing the two inner barks. The grafting should be done in a mild day, so the wax will work freely. Use no grease but tallow to put on your hands, to keep the wax from sticking to them, and not any more grease than is necessary, as it requires but little to kill a scion. To prevent the wind 
from breaking out the scion where it grows too fast the first Summer, it can be kept cut back to twelve to eighteen inches in length. The wax is made by boiling for five minutes after it is melted over a slow fire in a kettle that holds at least five times the amount of the following ingredients. Four pounds of rosin, two pounds of beeswax and one-half pint of boiled linseed oil. Stir it well and see it does not boil over; if inclined to, remove it from the fire for a minute or two, and then replace. When done pour it in a tub containing fifty times the amount of water to cool it, and then pull it as you would in making candy, for five minutes, and leave it in chunks the size of a ball. When wanted to use put it in warm water till it is soft.

The quince is one of the most profitable fruits grown and is one of the most neglected. 
It being a bush, its roots live near the surface of the ground. Its nature requires a very even degree of moisture throughout the growing season. It cannot stand excessive wet or dry conditions as well as fruit trees. If the quince bush fails to receive the necessary amount of moisture for the growing and maturing of its fruit at the last of the fruit-growing season, the fruit cells will break down, which makes a fine place for fungi to grow. In some cases the condition is so bad that the fruit is worthless. Light showers or dews prepare the skin over the broken cells of fruit to receive the fungii more readily. The cracking open of fruit is the result of a rapid growth following a stunted condition. The orchard should be cultivated often and shallow, and not allow weeds or a cover crop to take the moisture at the critical time of its development. These are some of the condi- 
tions when it is advisable to sow salt or cover the ground with a thick covering of hay, straw or any coarse mulching, to keep the air and sun from evaporating the moisture. The bush should be grown as a bush, and not with any length of body. It needs a little thinning out from the inside, otherwise it will adjust itself to conditions. It does best on rich soil. The bush does not have visible fruit buds, but grows one-half inch or more in the Spring before it blossoms. It depends on the amount of the matured vitality in the limb to set and hold its fruit. Like peaches and some other trees, it is often infected with borers, a little grub that lives on the inside of the tree. They are hatched from an egg that is laid in the bark near the ground by a fly that is easily caught by toads. The grubs are best dug out of the tree by using a quarter inch gauge chisel, starting at the hole leading to the grub 
that is apparent from the fine borings, and chisel out the bark by following the burrows left by the grub till it is found. Nature will soon heal the chiseled opening.

The fruit of the strawberry consists of a little pulp, a thin skin well filled with a highly flavored juice or water. When the plant fails to furnish the fruit with the necessary moisture for its development, the skin stops filling, leaving the berry of small size. A good way to aid the plant to get the necessary moisture is to plant the rows at least five feet apart and cultivate the ground as often as it is necessary to keep the land moist or mulch with litter and irrigate. The plant is a free feeder and does its best growing, in a comparatively few days, in the early part of the growing season.

The pulp of fruit consists of a combination 
of organisms that require a sufficient amount of fresh air to aid it in the completion of its cycle of life from the time it is picked till it reaches a decayed state, at which time it does not furnish nourishment to the animal system.

If fruit is picked when the temperature is above the normal and put in a close package in that condition, and stored in a close, unventilated room for any length of time, the cells of the fruit will commence to collapse, and will soon show it, in some varieties, in the form that is called scald, on the outside while it is ripening the fruit through its whole.

If fruit must be packed when it is hot, it should be put where the heat will be taken out as soon as possible, and kept with as little fluctuation of temperature as possible. A stream of water flowing through the room 
where the fruit is kept adds materially to its keeping quality, as shown in its firmness and flavor.

When the fruit is taken from the cold storage, its temperature should be raised gradually, to the height in which it is expected to be kept until used. Fruit that is frozen should be treated in the same way, to prevent it from showing its disastrous effect immediately. The warm, moist atmosphere of Spring has an ideal process of extracting frost from everything with as little loss of life as possible.

Trees, especially peach trees, should not be excessively cut back for the purpose of forcing a growth of a large sized fruit. It does not give a tree a chance to fully develop all its constructive parts. Under that condition it more readily succumbs to extreme 
climatic conditions and dies at an early age, and is more likely to be infected with insects and diseases.

The leaves, which constitute the manufacturing power of life, should be increased in numbers instead of decreased on every bearing tree and plant, that their combined work can produce more matured vitality in the short season of growth.

A little study on these lines will lead one to see where more leaves can be grown on a tree, and at the same time not interfere with the light and air striking the leaves located near where the fruit is growing.

Nature has provided for leaves to die when they get too thick, and shaded too much to be useful for growth. In this let nature have its way, at least on the leaves growing on the limbs and body near the ground. 


\section{A well enriched clay loam of good depth,} underlaid with porous red clay with some little gravel stones mixed in it, seems to be the strongest and best soil for the growth of all kinds of trees and plants; especially in flowers where bright colors are desired, the potash and iron that is more plentiful in such soil, form the basis of the colors in flowers and fruits. It is easier to keep the trees and plants in a continuous growth than in other soils. It is very clearly demonstrated in the blossoming of Hybrid Perpetual Roses, which require a strong continuous growth for a continuous blossom of large bright colored roses. Fruits and flowers grown on such soil have a solidity that adds materially to their keeping quality.

Home decoration and landscape attraction is becoming more appreciated than in former years, as there are many more who can have 
what was formerly reserved for the rich. In cultivating a taste for the best effect everything should be arranged so it will appear, on sight, to be just as it should be by nature. The house, located with reference to the road and other permanent improvements. The walks, leading from the house to the road or drive, where they would be most accessable for the greatest number likely to use them.

In locating the large growing trees which are likely to be the longest standing, make full allowance for the space they will occupy when full grown, whether they are set for beauty or shade, or their combination. Other space that would seem to be more attractive or restful to the eye, can be planted to smaller growing trees or shrubbery.

The selfish feature has so disappeared that the planting of hedges to keep the home 
isolated, or protected from mischievous people, has been largely done away with.

The lawns extended to the edge of the path, with beds containing attractive flowers a little way inside of the border, is too often to be admired, without little urchins playing on the lawn, that give the home its best effect.

The back yard, depending on its size, should be planted to vegetables and summer ripening fruits as they, by all means, want to be used when freshly picked. The largest trees should be located first, where, when grown, the limbs or shade of them will not extend over the line of the lot, other trees of smaller growing size should be located next, and then the berries and other small fruits. If the space is limited, grape vines can be used for covering screens and allowed to grow as high as is consistent with looks. 
The walks should extend around the garden and within a short distance of the fence or outside. The walk should be at least five feet wide, so that two persons can walk abreast and not be disturbed by the vegetables or berries growing near it. A liberal supply of flowering plants that are suitable for bouquets, will contribute oftentimes, to pleasant thoughts and admiration.

The liberal planting of Perennials make the garden look homelike and substantial.

Also the planting of crocuses, tulips and hyacinths, intermingled with the lily of the valley, planted near the walk, most frequented in early spring, will represent a feeling of good cheer with the advent of Spring in strong contrast of Winter. The sweet English violets having been previously admired as the promise of their coming. 


\section{In laying out a public park, the first} thought should be to have all of its entrances extending an invitation for everyone to enter, and enjoy its pleasant features.

If the park is large, its drives should be laid out, first in conformity with whatever the permanent interesting features there may be, and what is contemplated to be constructed. The entertaining features should be divided into two or more places. Those intended for children should be located where it is the easiest reached, that they may visit them often. Those intended more for grown people can be located further away, and in such places as will make the whole park interesting. The drives and paths should be wide, and graded to conform with the surroundings. They should be constructed with a tile drain in their center, laid at a depth of four or five feet, with frequent side outlets to let 
the water off. The ditch should be filled with one foot of coarse gravel, and above that with small size stones to the top, making a well drained bed to build the road on, whether of dirt, concrete or asphalt. The making of a dry road bed is the primary feature of making a road for durability, and will be used more extensively when people have learned its value. In putting the drain under the center of the road, it is not as likely to freeze as when put on either side, and is always ready to care for any water that comes to it. The deeper it is made and the longer it stands, the wider space and better it will drain.

In planting the larger growing trees, care should be taken to place them where they will not have to be removed. Never nearer than twelve feet of a drive, or six feet from a walk, if space will permit. 
There should be sun drives and walks, and shade drives and walks. In laying out the drives and walks, allowance should be made for their being made wider, when the use of the park is more fully developed. Trees planted in groups, forming little groves, are very desirable. Bright color flowering or foliage shrubs planted in masses are more at tracting than mixed varieties.

Unpleasant surroundings are better screened with mixed trees and shrubbery, than by hedges. Hedges, like fences, represent a restricted area which should not exist in an Americanized park.

The gymnasium feature of the park should be located on high and dry ground, and where the purest and best air can be had, as when growing children are exercising, they inhale more air, and it should be of the 
best. The trapeze, swings and other features should be sufficiently varied to use every muscle in the using of them and to fit the taste and enjoyment of as many as practical.

The birds and animals on exhibition should be of an elevating nature instead of demoralizing, as they oftentimes are.

There should be plenty of drinking places with the best of water, and places of necessity, not only sanitary, but respectfully kepr.

To have a cultivated plot where each individual class or school can have a vegetable and flower garden, is good to teach and encourage the human mind to have an interest in the earth's surface, and what and how things grow on it. Later it will inspire the desire to have a home of their own, the possession of which is a strong feature in nature, to become reliable, satisfied and interested in 
their good and the good of all others, which is well named Americanism.

Smaller parks can be laid out on these lines so contracted as to fit the size of the plot.

The fuel problem can, and will be solved, by the planting and growing of trees to be used for heating and other purposes. The Norway maple for the Northern states, and the Sycamore for the Southern states, have the lead over other varieties in hardiness, rapidity of growth, with comparative value for fuel and lumber purposes. Others are close seconds with specific values, such as catalpa and locus for posts and railroad ties, lindens, walnuts, ashes and pines for lumber. All of which can be grown in connection with other crops with great profit. By sowing their seed on a well prepared ground, 
the same as is used for wheat in the Fall, as soon as they can be secured after they are ripe, in rows four feet apart, with plenty of room at the ends for a horse and cultivator to turn on. The furrows for the seed to be sown in should be one-half inch deep, and four inches wide. Scatter the seed in it at the rate of about twenty-five seed to the lineal foot, and cover evenly with one-half inch of dirt. Care should be taken to see that the land does not crust in the spring, as such seed have but little lifting power when starting to grow in the Spring. In their wild state they are most always found starting under a light mould or leaves. The crust, if starting to form, can be broken by raking lightly as often as it starts, or covered with one-half inch of fine sand, and watered freely. The soil should be cultivated, hoed, and freed of weeds, the same as corn is cared for. When the seedlings have 
matured their growth, they should be dug in the Fall or the following Spring, and the center root cut off, leaving the root from eight to ten inches long, and all the side roots should be eut off to within one-eighth of an inch of the main root; this is for the purpose of preventing any roots being bent when set, as they often prove to be injurious in later years.

In planting them for the forest, first plow and fit the land the same as for corn, mark it out both ways, ten feet apart. Plant the trees with a dibble, be sure that you fasten the bottom of the root tight, and fill up the holes made by the dibble so the ground will not dry to injure the root. Put no manure or water near the plant when setting. Plant the field with hoed crops, and treat the trees the same as the crops till the trees get large enough to render the cropping unprofitable. The only 
trimming needed or allowable on the trees is to see that there is only one limb a growing in the center. When the lower limbs commence to die from the effects of their shade, cut out every other row diagonally, or as fast as it seems best for the good of the remaining trees. In planting do not mix nut bearing trees with seed bearing trees, as they are poisonous to them.

The most of forest trees and especially the black walnut, butternut and hickory are poisoning to fruit-bearing trees, and when standing too near them will kill them in time. The fruit-bearing trees show their effects by growing leaning away from them and the leaves show a weakness, indicating that the poison comes from the leaves as well as their roots. All leaves have a nature to repel each other. The stronger leaves absorb the vitality and take the place of the weaker ones. 
In heating your house with a furnace do not depend on it to force the hot air into the room that is already filled with air to heat it. Let the cold air, which is the heaviest, have a chance to pass out through a register located in or near the floor, and connected with a pipe leading to the bottom of the furnace, forming a vacuum in the room to be readily replaced with hot air from the furnace forming a circulation. The cold air from the room becomes lighter as it is warmed by the furnace. It is much less work to ventilate the house by opening the doors or windows, than it is to produce twice the necessary fuel needed to heat by induction, than it requires to heat by the circulation of air. Air, like water, when kept in motion, is much purer than when at rest or nearly so. 





\title{
THE SCIENCE OF FRUIT GROWING BASED ON NATURE'S LAWS
}

\author{
PART III
}

OR WHAT MAY BE MORE PROPERLY CALLED

THE THIRD YEAR'S WRITINGS

To produce a fruit-bearing tree containing the highest state of matured vitality that it may produce the largest percentage of firstclass fruit, it should have at least as much space for its roots to feed in where the sun's rays would strike it as is the space shaded by its most extended limbs. Many bearing orchards, where the trees are standing too near together to produce nice fruit, would be more profitable if one-half of the trees were 
cut out at the ground. Preferably taking every other diagonal row.

There would not be any beneficial results expected from taking the leaves from the lower one-third of a stalk of growing corn, tobacco or cotton plant, as soon as they are nicely formed. It is violating the same principle of growth in denying the fruit-bearing tree of the benefits that follow by having short twigs growing thickly on its body and along the larger limbs. At least one-half of nature's requirements to produce a properly developed fruit-bearing tree is taken from it by the present system practiced in trimming orchards.

In growing from the seed pines, spruces and such other trees as are found in their native condition growing in shady places, it is better to have the seed-bed shaded with cheese 
cloth placed from one to two feet above the ground for the first season, as the strong rays of the sun often burn them on their first appearance above the ground.

In transplanting pines and spruces it is best to choose the time when their buds are breaking to grow, it being found that they will overcome the injuries incidental to the transplanting more quickly, and with less loss, than when done at other conditions of the year's growth. If the tree is of large size in proportion to its roots (obtained by digging), it is an advantage to the tree to protect it from the sun and the evaporation of the winds by wrapping it with coarse burlap for a few weeks, while it is getting rooted.

If the season is bordering on a condition of drouth, the ground, for a circle of eight feet, should be heavily mulched and the dirt 
should be frequently wet to the depth of two feet, varying according to conditions, from once to twice a week, oftener if the conditions require it, to keep the ground moist, but not wet enough to prevent the air from penetrating the soil. Cold water from wells or hydrants, should not be used until its temperature is raised to that of the ground, by exposure to the air or other means.

If recently planted trees or bushes are slow in starting their growth at growing time in the spring, they can often be started by pouring a quart or two of as warm water as you can hold your hand in, over the limbs and body of them, allowing it to run down the body to the roots, at evening or on a cloudy day. A few applications will start the buds, after which, the tree will continue growing.

It is better to have recently planted trees 
start their growth promptly in the spring growing season. If the starting of their growth is delayed till in late spring or summer, they are liable to continue their growth too late in the fall and by it suffer from winter freezes.

When deciduous trees are being transplanted their leaves, if any are on the trees, should be stripped off at the time of digging. If allowed to remain they draw the moisture from the tree, putting it in a bad condition to stand future evaporation from the elements of the weather. A few minutes' delay in stripping the leaves in a warm, drying day, makes a difference of stripping to picking off the leaves. So deteriorating is the effect of leaving the leaves on scions cut for budding purposes, it is best to cut the leaves off from each scion as soon as it is cut from the tree. 
As some of the less hardy ornamental trees and shrubs can be grown in the Northern states by giving protection from the cold, the more hardy trees can be grown in parts of the Southern states, by protecting them from the hot rays of the summer sun.

The best specimens of the more tenacious fiber in trees such as hickory, white oak, orange and others, are found to be growing in their native places on land that has a deep, porous, clay subsoil; trees of less tenacious fiber are found on lands ranging from muck to sandy soil, or all combinations of them. While lighter soils can grow the trees and something of fruit, the best sizes and quality are obtained on land that is best adapted for their growth.

Care should be taken in preserving the new growth of trees in the cut-over forest with a 
view of continuing their growth to a proper size for timber. The waste of the cut-over timber, when too much to be saved for fuel, can be cut in small pieces and spread evenly over the ground to help hold the falling leaves and to form vegetable mold by decaying and at the same time to act as a mulch which is a great benefit to growing timber. It renders the conditions less liable for forest fires, which are admitted to be very disastrous to them. Trees growing in thick clumps can be transplanted, when of small size, to open spaces at an average of ten feet apart and others thinned by cutting out to approximately the same distance, this would give each tree a chance to grow from the first, instead of leaving them to grow in a battle of life under the law of the survival of the strongest, until nature has killed the surrounding trees and at the same time, the sur- 
vivor is weak and smaller in comparison with the tree growing in the open from the first.

The forest does not give very good timber from trees standing nearer than ten feet and in most cases the distance is thirty feet apart. Where big timber is desired, the trees can be thinned in later years when much of it taken out will be valuable for many purposes. Such varieties of trees should be grown in a forest as would be the most valuable timber when grown, as far as the soil and climatic conditions would favor.

Pits and nuts of trees can be successfully kept for several years, if desired, before planting, by burying them three or four feet deep in a moderately dry soil, as they will not germinate in soil of that temperature. The bacteria does not have the power at that depth of soil to decompose the 
hard, glue material forming the connecting shells of nuts, for several years. It is for this reason we find clover, and other plants, have grown from soil taken ten to twenty feet below the surface of the ground. We have no knowledge of the age of the seed from which the plants grew, they are mostly of those kinds of seed that are covered with a natural gum or rosin. Each kind of seed has its specific degree of heat and moisture necessary for its germination after which it battles for life through varied conditions of existence. In thinning out the trees in a forest such should be taken as are of minor importance when compared with the future value of those to be left, and the favorable chances for those to develop.

Every farm should have an orchard of nutbearing trees growing on it, of such varieties as are adapted to its soil and climate, as well 
as its fruit-bearing trees, bushes and vines. The oil taken from nuts when eaten, is more efficient to restore physical exhaustion, than animal fats or vegetable sugar and starch.

Trees whose nature show a tendency to grow upright and tall, have a corresponding nature for their roots to go deep into the ground, as shown by the sugar maple, oaks, spruces, oranges, standard pears and some varieties of apples, such as Northern Spy and Baldwin. Trees having more of a low-spreading top, such as Roxbury Russett, Rhode Island Greening, Birch, Elm, Hemlock and others, have their system of roots near the surface of the ground and can be made to flourish on shallower soil than the other kinds named; while they may live and grow, the fruit-bearing trees fail to produce satisfactory crops of fruit. 
Shallow soils are much improved in productiveness by deep underdraining which reduces the water of the soil to a lower level. In other places, ponds and small lakes with open ditches leading to them, located on the hill or mountain sides or any other place, to hold the surplus spring and flood waters until it could later percolate through the soil, would be helpful in connection with the vapor arising from them which would ameliorate the atmosphere and often check the disastrous effects of a drouth on forest or farming lands and furnish drinking places for livestock or to aid in putting out fires. The dry climatic changes brought about by the cutting of the forest and draining of swamp lands is so unfavorably affecting the growing of certain field crops in some sections, that other kinds of crops are being grown in their places. 
Plants or trees should not be watered too often or too much at a time when growing, as it tends to make the plant tender and more susceptible to bad results from climatic changes. If trees purchased are badly dried when received, it is better to bury them in moderately dry soil, sand preferably, for ten days or more before planting by burying the roots and three-fourths of the body and. limbs; the soil will frequently restore the dried condition to a plump, healthy state, when they can be planted with success. Do not wet the trees or ground when heeled in as described for gradually restoring the vitality; it has the same disastrous effect as taking the frost out of plants or trees too quickly. The tops of trees should not all be buried up when heeled in for recovery, as they seem to require air, even in that state.

The most natural climatic conditions to 
maintain the best service of the bacteria in decomposing the vegetable substance in the soil and fitting it into a digestible food for vegetable growth, is a warm, moist atmosphere. The variations from that condition affect growth in proportion to their extent. If cold, it slackens the circulation of its sap and respiration, the same as by a drouth. If hot, its growth is retarded by excessive evaporation, the same as by wind. Frequent stirring or cultivating the surface of the soil produces good sub-soil conditions for the right kind of bacteria to produce vegetable food for the more desirable and substantial products.

The more humus or vegetable matter incorporated in sandy and clay soils and their combinations, the better to produce bacteria of a fermenting condition similar to that of emptyings. This aids in the process of de- 
composing the ingredients in the soil that are necessary for the production of vegetable growth.

The more regular the fermenting condition in the soil and at the highest tension, the greater the rapidity of growth under warm, moist and sunny conditions. This fermenting process is sensitive to erratic changes, such as excessive amount of watering, cold atmosphere, extended drouth and the conditions incidental to it. The fermenting condition should be started as early in the spring as is consistent with good farming and continued with as little interruption as possible through the growing season. The more humus in the soil the less is the tendency of the surface to crust.

Grains, vegetables and fruits are much benefitted by radiated heat, that is heat rising 
from the ground, it seems to stablize the condition of growth and may carry with it valuable substances in the air that are beneficial to growth, as many plants of those that live and flourish in the air seem to do better in a location where there is an abundance of decomposing vegetable matter beneath them, such as orchids, dodder and others; a condition that is not the most healthful to the animal kingdom as is often seen by people living there having malaria fever and ague and other diseases caused by the bite of mosquitoes bred or produced from that condition.

Flat stones should not be placed on the surface of the ground around trees in such a position that the reflected rays would strike the trunks of trees, as the excessive heat produced by them is injurious to the trees, especially during the early or late parts of the growing season. If it is found convenient 
to put heavy stones on the roots of recently transplanted trees of large size to prevent the ill-effects of strong winds on them, the stones should be covered with dirt or a sufficient mulch to prevent the producing of strong reflected rays. Ripening grain, especially barley, when growing near young trees, has a similar effect on the trees as flat stones.

Quince and other soft wooded bushes are propagated by cuttings or layers. Sprout layers, which are the most sure, are obtained by cutting off the bush when from one-half to one inch in diameter, about three inches above the ground, before the buds start in the spring. The stub left will start many sprouts. When they are twelve to eighteen inches high or about the 1st of July, the lower part of the sprouts should be covered with fine, rich. soil to a depth of six to eight inches, depending on the growth made. A broad enough mound 
should be made so it will not dry out, the sprouts will soon turn root color and send out fine roots, making nice plants. These are cut off from the main stock each spring, leaving one-half inch of the sprout, after which other sprouts will grow, to be treated as before. They will increase in numbers each year as the plant grows older.

To propagate by cuttings, they should be cut from the stocks as soon in the fall season as the leaves are off and cut into short pieces about seven inches long, leaving one bud onehalf inch from the top, then tie in bunches not over six inches in diameter, and set in moist sand with the big end down in a moist cellar where they will not dry out until planting time in the spring. In the meantime the end of the cutting will callous over and often start roots. The land for planting should be well prepared and the cutting 
planted with as little exposure to the air in the act as possible; to puddle them is a great advantage. The cutting should be taken from the present season's growth and when planted, should be of such a depth that its top bud is just above the ground with the dirt well packed around it, especially the lower end. The cultivation should be the same as other plants require.

Vines can be rooted when growing by burying short sections of them six inches deep, every two feet, if done in July and allowed to remain in the ground for two years, in most cases, before taking up and dividing. All plants propagated from layers or cuttings, perpetuate their variety in fruits and flowers.

The tops of all root storing plants, especially sweet and Irish potatoes, should be severed from the plants as soon as they are af- 
fected by frost or blight, in order to stop the disorganized matter forming in the leaves and stalks from its effects, from being stored in the tubers, which would cause an early decay of the whole tuber and if eaten as food it would prove injurious to the consumer. Bush or tree fruits whose leaves have been destroyed prematurely by insects, blight or other causes, are of this same order of disorganized substances, as they do not change from their tannin stage of growth to a digestible starch or sugar condition as is necessary for the making of healthy animal substance or nourishment.

The pupa or grubs that feed on plants and their roots are becoming very numerous and destructive. Those that live in their pupa state in the ground are greatly reduced in numbers by plowing the land, especially in the fall, which turns their shell or cocoon over in 
which condition water can enter the shell through an opening, and kill the pupa that, by nature, is placed on the underside of the shell, a condition by which water cannot enter it. Many of their millers are caught by birds, wasps, hornets and other flying insects that live on their inferiors in strength and by unfavorable climatic changes when they are emerging from their pupa state. Otherwise they would control the growing condition of the world. When a tree, plant or animal is once infested with insects it is harder to rid it of them, as the insects breeding on it reduces the quality of sap or blood to a more palatable condition for them, under which conditions, they increase in numbers more rapidly. This is especially true of the white fly of the South and the pearpersilla and apple aphis of the North.

Too frequent spraying with thick material 
and arsenic poison, especially on the underside of the leaf, will reduce the vitality of many trees to such an extent that they cannot hold their fruit to maturity. Though they blossom profusely, the arsenic is absorbed through the pores of the leaf and limbs and has to be eliminated from the tree the same as from the system of a person. It fails to develop its fruit and leaves in size, solidity, and is in a receptive condition for fungus to grow. It impairs the vitality of the tree in proportion to the amount absorbed, and if too much is applied so the tree cannot eliminate it, it will kill the tree, root and branch. Arsenic is used to kill trees when it is desired to do so quickly and efficaciously, so that the roots will not sprout.

Arsenic, prepared the same as for spraying, diluted by $32 \mathrm{lbs}$. of water to one pound of arsenic, will kill trees, root and branch, if 
applied in comparative small quantities to the inner bark and outer wood of a tree. Arsenic is a stimulant to the animal system when taken for a short time in very small quantities. If continued, it impairs the circulation of blood, which accounts for the white appearance of the complexion of those who take it for that purpose. At the same time, it is destroying the life fiber throughout the entire system; it being accumulative, like lead poison, renders the system inefficient and later kills. The increasing numbers of pearpersilla and apple aphis, indicate a low state of vitality in the tree, that may have been produced by too frequent and excessive spraying with arsenic poison, covering a period of several years.

The worm and egg-eating birds should be protected in the forests as well as in the orchards and parks, from stronger birds, such 
as the butcher bird and others of its nature. The birds should be encouraged to live where needed by making houses for them and feeding them when they are unable to secure their feed on account of deep snow and too cold weather for them to get their worms.

The skunk, and other grub-eating animals, should be protected and furnished a place where they would feel safe to raise their young without being killed. Under such conditions they would continue their abode for many years and increase in sufficient numbers to be effective over a large acreage of adjoining crops.

The size and the number of kernels of grain growing in a single head of wheat, barley or rye, is determined, in large measure, by the regularity with which the plant is furnished its natural conditions for continuous growth, 
as well as its natural elements, in sufficient quantities to make the grain. The most necessary factor, as with animals, is air. The shortest omittance is effective when applied to either the leaves or the roots.

The next important factor for growth is the regularity of the moisture supply, the shortest omission of which shortens the circulation of its food supply and contracts its digesting process of growth, if only for a short time it has a noticeable effect in determining the number of kernels set and their size, in each head of grain. An over supply of moisture interferes with the digesting process of food, rendering it of a flatulent nature, instead of a completed product, as shown by a large number of kernels set with none reaching near a state of completion.

The necessary component parts for food 
and the soluble condition necessary for their absorption by the roots at all times, forms the basic material with which the other organs perform their work of construction. A liberal or scant supply determines the amount of grain the plant can produce, other conditions being equal. The less yield of grain in the older cultivated fields can often be traced to the land crusting over to a depth that shuts out the air which is a necessary factor to aid the bacteria in doing their work of preparing the food for the plant and furnishing the roots with their necessary amount of air with results as before stated.

The crusted surface can be broken by cultivating as is used for corn. The tools used can be of the same nature on a smaller scale, so constructed on a frame that several rows can be cultivated at a time, and drawn by a horse traveling in an open space formed by 
not sowing one row or two of grain, as is thought best, or one may accept of the small loss in comparison caused by the horse walking on the grain plants.

The cultivator should be guided by an automatic disc. This is constructed by using a cultivator handle attached to a shank carrying an eighteen-inch steel disc and this, in turn, is attached to and in front of a horizontal beam of the cultivator by a swivel. The disc is gauged to revolve in the ground to a depth of four to six inches, and is guided by the handle extending from it. The least variation in the guiding of the disc controls the course of the cultivator. The cultivator teeth should be attached to a jointed crossbeam so constructed that it would permit the teeth working in uneven places, each tooth should be gauged with a wheel going just ahead of it that would control the depth of 
the cultivation. The number of rows cultivated or the width of the cultivator would depend on the condition of the ground. The width of the drill used in sowing the grain would be preferable.

The grain should not be cultivated any deeper than necessary to break the crust and as often as it forms from the time the ground is suitable to work in the spring, until the grain plants, from size, are injured by the cultivator. If the crusted surface cannot be broken for a greater width than two inches, it will admit air that can penetrate in all directions to the roots. While the crusted conditions govern the growth of trees and production of fruit, the effects of their irregular growth are not so quickly discernible in trees as in the grains and smaller vegetable plants. 
Malted seed is a condition, when the seed has sprouted and grown from one-fourth to an inch, and then become stunted or killed for the want of natural conditions to extend its growth. A dry condition is the more serious as it more frequently contributes to it. This can be overcome, in a measure, by thoroughly preparing the seed bed by frequent cultivation and incorporating a liberal amount of vegetable humus in the soil before sowing the seed. If the soil is sandy or too porous to hold moisture, it can be frequently sprinkled, preferably at night and covered through the day with burlap or some similar material that will shade the ground until the plant can get started.

With field grains or plants on a larger scale, a liberal application of gypsum or refuse salt, will help to retain the moisture, the latter being the more efficient. The sprouted 
seed has usually got enough root growth started by the time the plant appears above the ground, to continue its existence.

Fruits that ripen in Summer and early Fall can be thinned to relieve an overburdened tree by picking, before harvesting time, the more matured specimens as soon as they will do to use for cooking purposes. The remaining fruit will grow better unless the tree has reached such an unfavorable condition that it could not overcome it, as is often the case when trees are suffering from the effects of over-bearing or drouth. In picking fruit, great care should be used not to pick the fruit tree spurs, as it takes several years to grow them.

Orchards should not be pastured with cattle, sheep or swine. If they are pastured with them the trees should be protected as high as 
they can reach with wire screen to protect their small twigs from being bruised by the cattle or sheep and prevent the swine from eating the bark, especially near the roots. Trees on which cats practice sharpening their claws should be protected, as it interferes with the health of the tree. Small pines, spruces and arbor-vitae growing on the lawn, should be protected from the frequent visits of dogs, their excretions spoiling the foilage and if continued, often kills the tree.

Teaching hogs to root for live roots by spreading corn or other grains on the ground, is bad practice. The best feeding roots of a tree are those that can be grown nearest to the surface of the ground that is consistent with good cultivation. The fine feeding roots correspond with the short, thick-leafed twigs of the body and larger limbs in producing a perfect growth. A gang plow, whose depth 
of furrow can be evenly gauged, is a good tool for working an orchard. If used cor. rectly, and often enough, it will keep the surface of the soil in good condition for growing the trees and kill all growing weeds and grasses without much additional dragging or culture except near the trees, which should be frequently and thoroughly hoed to kill the weeds and insects breeding in the soil. 
The copyright ownership of this book is hereby given, in trust, by its author, Virgil Bogue, to the Virgil Bogue Home for Dependent Children, at Albion, N. Y. The net income from which is to be used for the maintenance and care of its inmates. 
THE SCIENCE OF FRUIT GROWING

AND THE ART OF CULTIVATION

\section{Part IV.}

If the most of the terminal growth of a fruit tree is annually removed in the Spring to within one or two buds of its previous year's growth it would increase in proportion the terminal growth of that season over what it made the previous season. If this is continued for several years, it would tend to make the tree nonproductive of fruit. If it is thought best to keep the top of the tree as low down as is consistent for the variety it is better to cut one-half of the previous season's growth of the terminals each year until by bearing it reaches a shorter growth. If a fruit tree of suitable 
age and size does not bear, it often is from the fact that the growth is largely confined to the terminal limbs instead of being in the fruit spur buds. This can be changed by cutting off the new growing terminal limbs at the time they have stopped forming new leaves, which usually is before the first of August, after which the process of developing and maturing will be more confined to the fruit spurs that produce the fruit buds at that time of the year. This rule works well in older trees where the chief desire is the production of fruit, while the cutting off of the limbs will reduce the vitality of the tree, as every growing leaf cut from it does. It is not so vital an injury as the fruit bearing feature of the tree is developed by the removal of the terminal or scion growth at that time of the year. Fruit bearing trees from which the scions are cut in August for budding purposes are usually good bearing trees. This law of growth is applicable to fruit and vegetable bearing vines. By cutting off the terminal growth after the vines have 
reached a reasonable size growth for the season, it tends to give the older leaves a chance to increase the setting of fruit on vegetable bearing vines. It also develops and ripens earlier those that are growing on them, the same as the topping and suckering of tobacco makes the leaves develop in size and texture. When the seed and quantity of nourishing strength is desired, no part of the plant should be removed. The same is true of cotton, corn and other plants of a similar nature. The cracking open of the pealing and outer part of the fruit is caused by a more rapid growth following a partial contraction or ripening condition as is usually caused by a drought. The capillary action in forcing the sap into the growing fruit under favorable conditions possesses a great strength. It was found to possess an expanding power of several hundred pounds in a growing squash when one was confined in an iron bound box, so arranged to record its expanding power in pounds. 
Moss growing on trees should be removed from them. Their roots enter the inner part of the bark of the tree through the respiratory pores to live on the chlorophil or real life of the tree located or passing there. It clogs up the capillary channels through which chlorophil passes to the roots and other parts of the tree, as willow and other tree roots clog up a tile drain. The longer it is on, the more it injures the tree. The roots of moss can be killed by washing the moss with a strong lye, using a swab made by tieing a piece of cloth on the end of a stick, after which the rains will wash it off.

In planting orchards of fruit trees, different varieties should be planted in the same blocks to provide for pollenizing in emergency cases such as arises from continued rains or freezes occurring when the trees are in bloom. That kills the pollen or anthers on which the pollen is produced, when at the same time the ovules which receive the pollen through the stigma that is necessary for the setting and growing of 
the fruit is in a condition to receive it. There is usually enough late blossoms on the same tree to furnish the necessary amount of pollen; they, failing the stigma, will receive pollen from other varieties that have a later blossoming season. The same colored fruit should be set and when possible a variety possessing a stronger personal is desirable to set as is the case of a Sheldon pear, under the above stated conditions it will furnish the necessary polen for the Bartlett. The fruit will retain the shape and size of a Bartlett, but will possess the russet color and flavor of a Sheldon and ripen at the time of the Sheldon, which is a few days later. This point in nature varies in different varieties as in some apples, if one-fifth of the ovules receive pollen and is fertilized from another variety, it may be represented by a streak of one-fifth of the apple extending from the calyx to the stem in color and possess the more prominent characteristics of the variety of which it came. Or if the ovules are all fertilized with pollen from another 
variety the whole apple will possess the color and characteristics of the variety from which it came. Some varieties of grains and vegetables are more inclined to mix than fruits, as in the case of corn and squashes.

Fruit tree seedlings retain their individuality throughout their whole life. They influence the production and substance grown on the variety that is budded or grafted on them at or above the crown of the plant. Only such seedlings should be used to grow other varieties of fruit on them, as are constructively strong for bearing purposes. The larger and thicker leaf represents the better construction for growth. The smaller and thinner leaves are less efficient. All such seedlings should be thinned from the rows in September, when they can be more readily detected. If cut off at the crown at that time they will not sprout. The capillary channel of such inferior leaf plants are too contracted to produce sufficient growth to produce good fruit. They are more like the Horn- 
beam, or what is more commonly called lever wood which has a very fine texture and is of slow growth producing no fruits.

Acids are a natural product of the soil under certain conditions. They are assistants to bacteria in their work, to a limited extent. They often become over abundant and require reducing by the application of potash, lime or other acid neutralizing agencies to the soil, in order to grow the legumes and the better nourishing plants. Fxcessive amounts of acids are also held in check by surface and tile draining, as the most of soils that contain an excess amount of acids are those where the water level in them is near the surface the most part of the year.

The land should be thoroughly plowed and worked as early in the spring as possible and the hard packed soil just below the usual depth of plowing should be broken up in fine parts by a subsoil plow or a disk plow that does not turn up the subsoil to the surface but breaks it up in 
fine parts. Then with frequent cultivating and mixing of the soil to admit freely the light, warm rays of the sun and air it will prove very effective.

Nearly four-fifths of the air is nitrogen which is a great neutralizer of acids. Its efficiency is readily determined by exposing strong vinegar in shallow containers located in a current of air. Dropped fruit containing acids should not be plowed into the ground, as it requires more potash, lime and other elements to neutralize the acids that the soil has absorbed from them. The potash used for that purpose has no further value as is shown by putting a little saleratus made from potash in a glass of sour cider. Its neutralizing effect makes the cider more palatable and at the same time the potash and acid become extinct. By keeping the soil in a receptive state to receive the natural agencies to neutralize acid more of the artificial agencies that have to be procured at high prices can be reserved for the making of plant food, 
The thorough summer following of the land as formerly practiced for growing wheat, neutralizes the acids and insures a good crop following, when other conditions are favorable. The nitrogen in the roots and nodules of a good crop of legumes when plowed under is sufficient to neutralize the acids in the soil to insure a good crop of most anything planted for one year. The frost coming out of the frozen ground in the spring leaves the soil porous, through which the air enters and neutralizes the acids. Under such condition the land should not be worked in the spring until the air has dried out the soil and done its best work at neutralizing the acids, to insure a good vegetable growth for that season.

Fruit trees standing on knowls that are more of a wet and springy nature than the surrounding land, as is often indicated by a spontaneous growth of sorrell, are more likely to be affected with acid canker crown rot than others surrounding them. These knowls are the natural vent holes of the ground where the water and acid level 
come to or near the surface. Similar in nature to the air holes in ice covering a pond that the skater learns to avoid. The knowls require more manure to nullify the action of the acid in order to grow an equal amount of vegetable growth that is produced on the surrounding land.

It is better to plow a little deeper than usual when turning under a green crop or summer following.

The frequent dying of shade trees located in the paved streets of cities, is largely due to acid action on the roots as shown by the decayed condition of them, and the location near the surface of the ground of what few live roots there may be left on the tree and the decaying of the trunk at and above the ground. This condition can be prevented in a large measure by deep and thorough tiling the soil under the trees or placed along side the sewer pipe in the center of the road, and keeping the soil loose that is located at the base of the tree and nearby places of ground where it is 
possible for the air to penetrate, and work into the ground a liberal amount of potash, lime and humus forming manure for the roots to feed on and to help to keep the soil porous. The present decayed conditions of the roots of many of the large trees are so bad they should be removed for safety's sake, and others put in their places.

Noxious sewer gases escaping through the ground nulifies bacteria action to that extent it injures the trees and often kills them.

Fruit trees suffering from the effects of too much water in the ground, when growing show it by large irregular shaped, yellow, brown or black dead blotches on the ends and sides of the leaves, indicating a breaking down of the cells of the leaf. The fruit cells are effected in the same way, which produces on the skin the right conditions for fungii to grow.

Fruit trees suffering from too damp atmosphere show it by nearly round spots 
on the leaves and fruit. They increase in size and number as the conditions continue and furnish suitable places for fungii to grow.

The elastic nature of plant growth is so great that many imperfections are not readily discernible though they are effective in the construction of flowers, grains and fruits. It is for the interest of the grower to see that the imperfect conditions for growth are reduced to the minimum and the most favorable conditions for growth are furnished to the maximum.

Pure sand, clay, air or water taken alone will not produce vegetable growth. Mix sand and clay together thoroughly so it will admit air freely and add enough water to moisten it and it will produce vegetable growth. The clay possesses the requisite material but lacks conditions for other elements to act on it. Fruit bearing trees growing in sand that are dependent mostly on commercial fertilizers for their success should be furnished with it regularly at least every two weeks or oftener 
throughout the cultivating season in order to produce a regular and continuous growth. The fertilizers should be cultivated into the ground as deep as is consistent with the location of the feeding roots as soon as it is sown.

Applying an excessive amount of fertilizer at one time interfere with the digesting of the elements the same as with the animal system. It violates the essential law of frequent and regular feeding which is taught by every living thing. The clay loams that have the power of absorption and retention of the mineral substances until used by the roots is a different proposition, it is not so dependent on frequent renewal of plant food.

The water level in the forepart of the growing season controls the acid level in the soil. The acid and water level and the compactness of the soil governs the kind of bacteria and its energy in producing the more valuable vegetable growth. The reason of the roots of plants and some of the 
larger trees existing near the surface of the ground is that the acid level will not permit vegetable growth below where the roots exist. Grasses, plants, bushes and trees that can live in soil that is heavy laden with acids have acquired a nature to live near the surface of the ground, or in dwarf condition. Their would-be brace roots are so often destroyed by the acids they cannot produce an extended upright growth as they have no brace roots to sustain them. On natural deep porous soils or deep tile drained land the roots are found to exist at a much greater depth, the same is true of cereal and vegetable plants. The acid level in the ground can be located and the comparative amount can be measured by the use of blue litmus paper. Put a strip of it from the bottom of a hole dug as deep as you wish to test it, to the surface of the ground and fill up the hole with dirt, packing the soil as you put it in. After it has remained a few hours remove the paper. At the depth where the paper has turned red is the location of the acid level. 
The brightness of the red color and the length of the time it requires for the acids to change the color from blue to red represents the density of the acids. If this same blue litmus paper turned red by the acids is soaked in a pint of rainwater with a little potash added it will restore the blue color. The quantity of potash required to restore the color represents the density of the liquid and at the same time the density of the acids that turned the color from blue to red. If there are not enough acids in the soil to turn the blue litmus paper to red there are not enough acids in it to injure vegetable growth. The conditions vary at different times of the year. The most serious is the early growing season.

The excess amount of acids in trees more than what is used in the regular process of growth is eliminated in the form of canker, as is shown by the dead bark at and above the crown of the tree and extending upward on the trunk and on the lower limbs near the main trunk, after the canker has 
killed the live substance located at those places and by the spots on the fruit and leaves which indicate the health of the whole tree is in bad order, or in nematodes that live on the unmatured fruit producing properties in the tree. When too abundant they show their effect in the form of death, called blight, which appears in the greatest abundance just previous to, or at the time of producing its first crop of fruit, indicating its favorite food is unmatured fruit vitality. This can be obviated in a as tends to produce matured vitality, in order to bring about an early abundant bearing of fruit instead of a flatulent growth. After trees become regular bearers they are not affected as much with acid blight. The-principle of bearing to promote health is abundantly demonstrated in the history of the health and strength of our grandmothers who bore large families.

A nematode is a parasite with a worm form and habits, that exist in animal and vegetable life. The most active acid nema- 
todes can be seen in vinegar with a magnifying glass. The nematodes are found in the greatest abundance in the parts of the tree just below where the limbs are wilted from blight, and often works out through the bark in the apparent form of gum substance. If the limb is removed as it should be for a foot or more below the blighted parts as soon as seen to be wilted and burnt, it will save their extending downward for more feed or being carried by bees or the wind to other trees alighting usually on the blossoms where they find a natural food to feed upon. Their presence is noted in a short time by the near-by leaves turning black and the dying of the more succulent part of the bud and fruit spur. The more matured part of the fruit spur most always resists the action of the nematodes and stops its extending farther. Similar conditions often exist when the growth of the tree is so flatulent that the spreading nematodes can act on the new terminal growth, producing what is called "twig blight." Their action is often check- 
ed when they reach downward to a more matured growth. After the canker and trachina nematodes have done their work of disorganizing life substance the bacteria germ takes possession and decomposes the lifeless properties existing there. While the nematodes can exist in a dormant state in live matter the decomposing bacteria can only exist in a foreign or dead substance susceptible of being decomposed.

The dead spots in the bark of the trunk and larger limbs of pear trees and the spots that are nearly dead are the results of acid action on the life substance there. The inner layers of bark are often reinvigorated with chloraphil after which the tree may live many years before dying or it may never die from its effects. Acid action does its worst work, in trees when it is a more than ordinarily wet time. Its effects may be seen soon or it may not be seen for some time after. 
The knife or the saw used for the amputation of the limbs should be sponged with a solution of Corrosive Sublimate having the strength of one part to five hundred of water before using for cutting of the next limb to prevent the spreading of the germs.

To prevent and check the activities of trachina nematodes it is best to lower the acid level in the ground by surface and deep tile draining to remove the water level and apply a liberal amount of manure of a developing ripening and acid neutralizing nature and prevent the effects of extended drouths by frequent and thorough cultivation of the soil and introducing into the soil when necessary a liberal amount of salt to aid in conserving moisture, that the feeding roots can flourish near the surface instead of having to go deep into the ground for moisture only to be caught in the lower water and acid level at the next late wet spring and summer, with its disastrous effects. The acid action on trees is one of the factors that reduces the quality 
of the sap, to a palatable condition to admit the sucking insects to flourish on it, such as the case bearers, aphis, pear percilla, and white fly. The acid action on the inner cells of the fruit kills the cells and renders the chlorophil inactive. After which the cell or combination of cells turn yellowbrown, forming a spot, as we oftentime see in an overgrown apple, more especially the Baldwin. The acid action on the cells of growing fruit makes spots available where the fungii can grow.

If the trees are growing in sod or under neglected conditions it is better to start the change in cultivation by plowing and dragging the land in the late fall or early winter so that the decomposing bacteria can commence its active work as early in the following growing season as the warm weather will permit and the growth of the trees can be completed before it is too late in the fall in order that the life substance in the tree can stand the debilitating effects of winter without too much loss of vitality. 
It is a good indication of a fruit crop when the leaves on a fruit-bearing tree get a good start in growth in the spring before it blossoms. When a tree blossoms before the leaves start it indicates a low state of vitality and is not as likely to set or hold its fruit till picking time.

The thin layers of wood representing the annual growth as is often found in sawed lumber to be much smaller in the first five inches from the heart of the tree than those farther from the heart or center, shows the results of forest trees growing too near together when young. The larger layers show the progress the tree made after it had gained its supremacy over its competitors. At the time of making those restricted growths, it should have been making by nature its best growth, if the trees had been properly thinned when young.

If the lower limbs could be correctly removed by the method and at the proper season of the year as previously stated, 
when they show signs of dying from shade, many of the would-be knots that would be formed by allowing the limb to die and remain on the tree until they fall off, would be eliminated by the process of healthy growth.

The soft early decaying spots that are found in lumber aside of what is known as the sap part, is often caused by the tapping of the maples, turpentining the pines, excessive dry seasons and the late spring freezes or the foliage being eaten by insects that impair the natural growth though it may be only for one season. 


\section{INDEX}

Acids ...................... 123

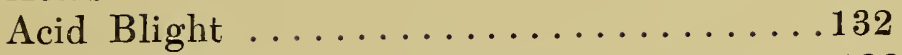

Acid Control .................... 123-3

Acid Controls Bacteria Action....... 126-3, 129-3

Acid Density Determined . . . . . . . . . 131

Acid Level Located with Litmus Paper... . . 130

Acid Producing Canker and Blight..... 125, 131-2

Acid Producing Nematodes.............. 132

Air Cells .................... 6-2

Annual Bearing . . . . . . . . . . . . 60-2

Apple Coloring . . . . . . . . . . . . . . . 52-2

Apple Leaf . . . . . . . . . . . . . . . . 5 5-2

Arsenic Poison ................5-2, 104-2

Bacteria \& Cultivation ... . . . . . . . 11-2, 109

Bacteria ..............41-3, 42, 96-2

Bark Bound ................. 46-2

Best Feeding Roots . . . . . . . . . . . 114-2

Bird Protection .............106-2, 34

Blight, its Cause and Prevention.......133, 135

Blossoming Feature ............. 56

Buddink .................. 15

Budding from Bearing Trees........... 17-2

Capullary Action Power...........................

Care of Cut over Forrest............ 90

Care of Picked Fruit............. 67-2

Care of Transplanting ............. 17-2

Chlorapast ................. 4-2

Clhoraphil .................. 47

Circulation of Sap $\ldots \ldots \ldots \ldots \ldots \ldots .9$ 
Clay Loam ................... 71

Climatic Condition .............. 96-2 Cold Water .................. 88 Coloring of Leaves and Fruit........50, 52 Cracking Open of Fruit ..............119 Circulation of Sap ............. $7-3,9$ Crust Breaking Tool................ 109-2 Crust Cultivating .................. 109 Cultivation .................. 13, 25 Curing Fruit ............... 33 Cutting Back Trees .............. 69-3 Cutting Out Trees .............. 85 Decayed Fruit ................ 32 Deep Soils and Under Draining.........94, 95 Depth to Plough ................ 48 Dog and Cat Nuisances .............114 Drought $\ldots \ldots \ldots \ldots \ldots \ldots \ldots \ldots . \ldots 58$ Early Cultivation .............. 98 Electric Storm ............. 7-2 Elements Necessary for Growth. . . . . . . 107-3 Fall Plowing .............32, 40, 136-2 Fall Plowing \& Fungis ............. 32 Fermenting Condition ............... 97-2 Forestry ....................... 137 Frozen Fruit ...............69, 31 Frozen Leaves and Stems........... 31-2, 102-2 Fruit Growing Season.............. 39 Fruit Spurs ................ 15-2

Fruit Spur Ages ................113 Forestry and Fuel Problems.......... 79 
Fertilizers . . . . . . . . . . . . 13-2

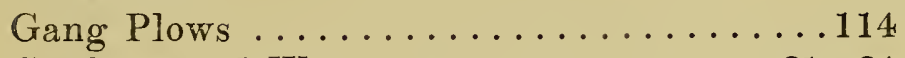

Grafting and Wax ............61, 64

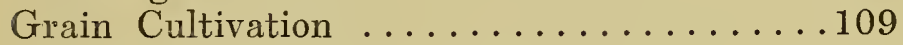

Growing Forest ................ 81, 86-2

Growing Twigs on the Body........... 86

Grubs ....................... 103-2

Gymnasiums ................. 77-3

Heating a House . . . . . . . . . . . . 83

Heat and Light $\ldots \ldots \ldots \ldots \ldots \ldots \ldots \ldots \ldots$ 4t-2

Hornets . . . . . . . . . . . . . . 36

Individuality of Fruit . . . . . . . . 14-3, 122-2

Influence Seedlings have in Fruiting.......122

Keeping Pits ................. 92-2

Lake Influence . . . . . . . . . . . 13-3, 95

Landscape . . ................ 71-2

Leaves ..............4, 6-2, 30, 32, 69-2

Leaves Necessity . . . . . . . . . . . . . 16, 17

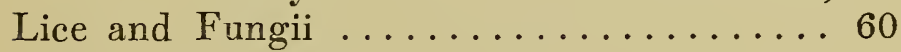

Light and Chloraphil ............. 29-3

Life in Trees ................7-3 8-2

Life Substance ................ 10-2

Malacules .................... 8-2

Malted Seeds . . . . . . . . . . . . . . . 112

Manuring . ................27, 40, 128-2

Matured Vitality ................ 11

Mixing Varieties for Pollinizing. . . . . . . 120-2

Moisture for Growth . . . . . . . . . . . 12-2

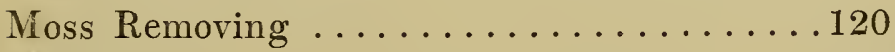

Mulching $\ldots \ldots \ldots \ldots \ldots \ldots \ldots \ldots$ 87-2 
Natural Agencies to Neutralize Acids...... 123

Necessity of Air for Growth . . . . . . . . . 107-3

Necessity of Moisture .............. 108

Necessity of Food .................. 108-3

Nematodes Described . . . . . . . . . . . 132-2

Nematode Spreading . . . . . . . . . . . . . 133-1

Nut Tree Orchards . . . . . . . . . . . . 93-2

Oxigen Necessity ........................ 30

Parks .................... 75

Pasturing Orchards ..............113-2

Perfect Fruit .................. 59-2

Picking Early .................................. 31

Pollenizing Conditions .............. 120

Poison Sprays .................. 104-2

Poisonous Trees ................. 82

Planting Trees ................. 17-2

Producing Baocteria .............. 97-2

Productiveness .................. 16-2

Propagating by Layers and Cuttings....... 100

Quinces .................... 64

Radiated Heat .................. 98-2

Reflected Heat .................. 99-2

Regular Fruiting ........................ 60

Regular Growth ............... 47

Removing Frozen Tops............................

Respiratory Organs ............44, 52

Retention of Individuality in Seedlings.... 122

Reviving Dried Trees ............. 96

Ripening Condition . . . . . . . . . . . 5 58-2

Roots ...................24-2, 114-2 
Root Eating Grubs ............... 103-2 Roots Feeding .................. 28

Salt . . . . . . . . . . . . . . 29-2

Sap ..................... 9-2

Sap Quality .................. 28

Scalded Fruit ................ 68-2

Seasons Control ............... 42-3

Setting of Fruit ................. 55-2

Sewer Gas . . . . . . . . . . . . . . 127

Shading Seed Bed ............. 86

Short Seasons . . . . . . . . . . . . . 39

Skunks ..................34, 107

Snakes ................... 34-3

Spraying ..................49- 5-2

Starting and Planting an Orchard....... 17-2

Starting Delayed Growth............ 88-2

Starting Fruit ................ 80

Strawberries .................. 67

Stripping Leaves Before Digging........ 89-2

Structure of Leaf . . . . . . . . . . . . 16-2

Sun-Light for Fruit ........... 14-2, 85

Sun Light for Growth. . . . . . . . . . . 13

Sun's Effect on Roots.............. 85

Tanning, Starch and Sugar.......... 33-2

Tender Trees ..................990

Thinning Fruit ............57, 113

Time to Cut Bushes to Kill Them........ 22-2

Time to Pick Fruit..............31-3 33

Time to Trim...............23, 47-2

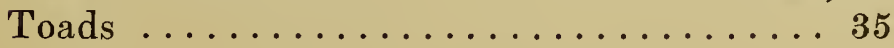


To Kill Land Insects . . . . . . . . . . . 103-2

Transplanting Deciduous Trees......... 89 Transplanting Pines . ............. 87 Trimming When Trees are Young........117 Trimming . . . . . . . . . . . . . 19, 47-3 Trimming to Produce Fruit.............118 Trimming to Produce Ripening........... 118 Trimming, When Not To.............117 Vent Holes for the Ground.............125 Vitality $\ldots \ldots \ldots \ldots \ldots \ldots \ldots \ldots \ldots \ldots$ Water Controls Acids................ 129-3 Water Surplus . . . . . . . . . . . . 127-3 Watering Plants ................. 96 Water Purifier ................. 68-3

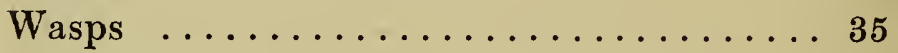
Woodpeckers $\ldots \ldots \ldots \ldots \ldots \ldots \ldots \ldots 36$ 




\section{LIBRARY OF CONGRESS

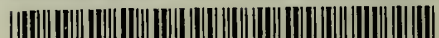

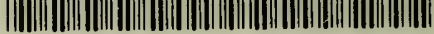 000091708 ?A}

